\title{
Sistem Peramalan Kebutuhan Hidup Layak Minimum (Kapita/Bulan) Kota Bandung
}

\author{
Rifqi Fahrudin ${ }^{\mathrm{a}}$, Irfan Dwiguna Sumitra ${ }^{\text {ab }}$ \\ ${ }^{a}$ Magister Sistem Informasi, Universitas Komputer Indonesia \\ bJurusan Manajemen Informatika, Universitas Komputer Indonesia \\ Naskah Diterima : 12 Agustus 2019; Diterima Publikasi : 31 Oktober 2019 \\ DOI : 10.21456/vol9iss2pp192-203
}

\begin{abstract}
The importance of inflation forecasting is used as a reference for estimating the Need for Living (KHL). If inflation can be predicted with high accuracy, it can certainly be used as the basis for government policy making in anticipating future economic activity. This study aims to produce a model of inflation data forecasting system, the forecasting results can be used as a reference for determining the Decent Living Needs (KHL) of a single worker in one month. The data used in forecasting is inflation data for January 2011 - December 2017 while the KHL data for the food and beverage category is obtained from the food price portal. The method used in this study is the SARIMA-SES hybrid method. In forecasting the inflation rate where the data is in the form of time series, the SARIMA-SES hybrid method can show more accurate forecasting results than using a single method. Based on the comparison of the overall forecasting model and by combining the SARIMA $(1,0,1)(1,0,1) 12$ and SES models with alpha 0,6 the smallest error value with MAD value 0,114, MSE 0,017 and 0,39\% for MAPE. From these results, it was gathered that inflation forecasting in Bandung City using the SARIMA-SES hybrid method has a high accuracy value so that the results of the KHL value calculation with the forecasting inflation value approach the actual value. From these values can be used as a reference for the decision making of a single worker in fulfilling their life needs one month.
\end{abstract}

Keywords: Inflation; Forecasting; SARIMA; SES; KHL

\begin{abstract}
Abstrak
Pentingnya peramalan inflasi untuk dijadikan acuan perkiraan Kebutuhan Hidup Layak (KHL). Jika inflasi dapat diramalkan dengan akurasi yang tinggi, tentunya dapat dijadikan dasar pengambilan kebijakan pemerintah dalam mengantisipasi aktivitas ekonomi di masa depan. Penelitian ini bertujuan untuk menghasilkan model system peramalan data inflasi, hasil peramalan tersebut dapat dijadikan acuan untuk penentuan Kebutuhan Hidup Layak (KHL) seorang pekerja lajang dalam satu bulan. Data yang digunakan dalam peramalan adalah data inflasi Januari 2011 - Desember 2017 sedanagkan data KHL kategori makanan dan minuman didapatkan dari portal harga pangan. Metode yang digunakan dalam penelitian ini adalah metode hybrid SARIMA-SES. Dalam peramalan laju nilai inflasi dimana data berupa time series, metode hybrid SARIMA-SES dapat menunjukan hasil peramalan yang lebih akurat dibandingkan dengan menggunakan metode tunggal. Bedasarkan perbandingan model peramalan secara keseluruhan dan dengan penggabungan model SARIMA $(1,0,1)(1,0,1)^{12}$ dan SES dengan nilai alpha 0,6 menghasilkan nilai error terkecil dengan nilai MAD 0,114, MSE 0,017 dan 0,39\% untuk MAPE. Dari hasil tersebut disumpulkan bahawa peramalan inflasi Kota Bandung menggunakan metode hybrid SARIMA-SES memiliki nilai akurasi yang tinggi sehingga hasil kalkulasi nilai KHL dengan nilai inflasi hasil peramalan mendekati nilai aktual. Dari nilai tersebut dapat dijadikan acuan untuk pengambilan keputusan seorang pekerja lajang dalam memenuhi kebutuhan hidup satu bulan.
\end{abstract}

Kata kunci: Inflasi; Peramalan; SARIMA; SES; KHL

\section{Pendahuluan}

Inflasi merupakan kecenderungan atau gerakan naiknya tingkat harga umum yang berlangsung secara terus-menerus dari suatu periode ke periode berikutnya. Pentingnya peranan inflasi dalam menentukan kondisi perekonomian, sehingga perlu adanya perhatian serius dari kalangan otoritas moneter yang bertanggung jawab mengendalikan inflasi. Jika inflasi dapat diramalkan dengan akurasi yang tinggi, tentunya dapat dijadikan dasar pengambilan kebijakan pemerintah dalam mengantisipasi aktivitas ekonomi

*) Penulis korespondensi: irfan_dwiguna@unikom.ac.id di masa depan. Indikator yang sering digunakan untuk mengukur tingkat inflasi adalah Indeks Harga Konsumen (IHK). Undang - undang No. 13 Tahun 2003 tentang ketenagakerjaan menyatakan bahwa setiap pekerja/buruh berhak memperoleh penghasilan yang memenuhi penghidupan yang layak bagi kemanusiaan pada Undang - Undang No. 13 (2003).

Berdasarkan Peraturan Menteri Tenaga Kerja dan Transmigrasi RI No.17 tahun 2005 tentang Komponen dan Pelaksanaan Tahapan Pencapaian Kebutuhan Hidup Layak menyatakan bahwa kebutuhan hidup layak adalah standar kebutuhan yang harus dipenuhi 
oleh seorang pekerja lajang untuk dapat hidup layak baik secara fisik, nonfisik dan sosial untuk kebutuhan satu bulan pad Peraturan Menteri Tenaga Keja dan Transmigrasi RI No. 17 (2005). Komponen kebutuhan hidup layak sebagai dasar dalam penetapan upah minimum merupakan peningkatan dari kebutuhan hidup minimum pada Peraturan Pemerintah No.78 (2015).

Kebutuhan Hidup Layak yang selanjutnya disingkat KHL adalah standar kebutuhan seorang pekerja/buruh lajang untuk dapat hidup layak secara fisik dalam satu bulan. Berdasarkan PP. No.78 tahun 2015, penyesuaian nilai KHL secara langsung terkoreksi melalui perhitungan dengan tingkat inflasi nasional tahun berjalan. Jumlah jenis kebutuhan yang semula 46 jenis dalam Keputusan Menteri Tenaga Kerja No. 17 tahun 2005 menjadi 60 jenis KHL dalam Keputusan Menteri Tenaga Kerja No. 13 (2012). Peramalan adalah metode untuk memperkirakan suatu nilai di masa depan dengan menggunakan data masa lalu. Data inflasi merupakan salah satu data runtun waktu, dengan memodelkan data waktu lampau dapat digunakan untuk meramalkan data waktu mendatang. Dalam peramalan laju nilai inflasi dimana data berupa runtun waktu, metode Seasonal Autoregressive Integrated Moving Average atau lebih dikenal dengan metode SARIMA dapat menunjukan hasil peramalan yang mampu mengikuti pergerakan data aktual dari laju nilai inflasi.

Penelitian ini akan menggunakan serta menggabungkan metode SARIMA dan SES dengan melihat adanya pola musiman sebagai usaha untuk menghasilkan peramalan yang lebih akurat dan mendekati nilai aktual. Perlu adanya perhitungan KHL bagi seorang pekerja lajang,dalam memenuhi kebutuhan hidup layak baik secara fisik maupun non fisik. Dari hasil peramalan nilai inflasi akan dikalkulasikan dengan KHL untuk menentukan nilai KHL bagapada periode berikutnya sesuai dengan hasil peramalan nilai inflasi.

\section{Kerangka Teori}

\subsection{Inflasi}

Inflasi adalah suatu keadaan yang mengakibatkan naiknya harga secara umum atau proses meningkatnya harga-harga secara umum dan terus menerus berkesinambungan pada Suseno, S. A. \& Siti Astiyah (2009). Inflasi dengan kata lain merupakan proses menurunnya nilai mata uang secara kontinu. Inflasi merupakan proses suatu kejadian dan bukan tinggi rendahnya tingkat harga. Sehingga, jangan menganggap kalau tingkat harga tinggi itu berarti inflasi tinggi. Inflasi terjadi kalau proses kenaikan harga yang terus menerus dan saling pengaruh mempengaruhi. Indikator yang sering digunakan untuk mengukur tingkat inflasi adalah Indeks Harga Konsumen (IHK) pada Swandayani, D. M., \& Kusumaningtias, R. (2012). Indeks harga konsumen adalah ukuran rata-rata perubahan harga dari suatu paket komoditas dalam suatu kurun waktu tertentu.

\subsection{Kebutuhan Hidup Layak}

Berdasarkan Peraturan Menteri Tenaga Kerja dan Transmigrasi RI No. 17 tahun 2005 tentang Komponen dan Pelaksanaan Tahapan Pencapaian Kebutuhan Hidup Layak, menyatakan bahwa Kebutuhan Hidup Layak adalah standar kebutuhan yang harus dipenuhi oleh seorang pekerja lajang untuk dapat hidup layak baik secara fisik, nonfisik dan sosial untuk kebutuhan satu bulan. Jumlah jenis kebutuhan yang semula 46 jenis dalam Keputusan Menteri Tenaga Kerja No. 17 tahun 2005 menjadi 60 jenis KHL dalam Keputusan Menteri Tenaga Kerja No. 13 tahun 2012. Selain penambahan 14 jenis baru KHL tersebut, juga terdapat penyesuaian/ penambahan Jenis kualitas dan kuantitas KHL serta perubahan jenis kebutuhan. Berikut komponen komponen makanan dan minuman standar Kebutuhan Hidup Layak berdasarkan Keputusan Menteri Tenaga Kerja No. 13 tahun 2012 seperti yang terlihat pada tabel 1:

Tabel 1. Standar Kebutuhan Hidup Layak

\begin{tabular}{|c|c|c|c|}
\hline No & Komponen & $\begin{array}{l}\text { Kualitas/ } \\
\text { Kriteria }\end{array}$ & $\begin{array}{l}\text { Jumlah } \\
\text { Kebutuhan }\end{array}$ \\
\hline \multicolumn{4}{|c|}{ I. Makanan dan Minuman } \\
\hline 1 & Beras Sedang & Sedang & $10 \mathrm{~kg}$ \\
\hline \multirow[t]{4}{*}{2} & Sumber Protein : & & \\
\hline & a. Daging & Sedang & $0.75 \mathrm{~kg}$ \\
\hline & b. Ikan Segar & Baik & $1.2 \mathrm{~kg}$ \\
\hline & c. Telur Ayam & Telur Ayam & $1 \mathrm{~kg}$ \\
\hline 3 & $\begin{array}{l}\text { Kacang-kacangan : } \\
\text { tempe/tahu }\end{array}$ & Baik & $4.5 \mathrm{~kg}$ \\
\hline 4 & Susu bubuk & Sedang & $0.9 \mathrm{~kg}$ \\
\hline 5 & Gula pasir & Sedang & $3 \mathrm{~kg}$ \\
\hline 6 & Minyak goreng & Curah & $2 \mathrm{~kg}$ \\
\hline 7 & Sayuran & Baik & $7.2 \mathrm{~kg}$ \\
\hline 8 & $\begin{array}{l}\text { Buah (setara } \\
\text { pisang/pepaya) }\end{array}$ & Baik & $7.5 \mathrm{~kg}$ \\
\hline 9 & $\begin{array}{l}\text { Karbohidrat lain } \\
\text { (setara tepung terigu) }\end{array}$ & Sedang & $3 \mathrm{~kg}$ \\
\hline 10 & Teh atau Kopi & Celup/Sachet & $\begin{array}{l}2 \text { Dus isi } \\
25\end{array}$ \\
\hline 11 & Bumbu-bumbuan & Nilai $1-10$ & $15 \%$ \\
\hline
\end{tabular}

Selengkapnya mengenai komponen Kebutuhan Hidup Layak (KHL) dapat dilihat dalam Keputusan Mentri No. 13 tahun 2012.

\subsection{Peramalan}

Peramalan adalah kegiatan untuk memperkirakan apa yang akan terjadi pada masa yang akan datang (Sofyan, 1984). Peramalan merupakan bagian vital bagi setiap organisasi bisnis dan untuk setiap pengambilan keputusan manajemen yang sangat signifikan. Peramalan runtun waktu adalah serangkaian pengamatan terhadap suatu variabel yang diambil dari waktu ke waktu dan dicatat secara 
berurutan menurut urutan waktu pada W. W. S. Wei, (2006).

\subsection{SARIMA}

Seasonal Autoregressive Integrated Moving Average atau yang lebih dikenal SARIMA adalah metode peramalan time series untuk model data fluktuatif dengan pola data musiman (Pongdatu \& Putra, 2018).

Secara umum, notasi SARIMA adalah:

$\operatorname{SARIMA}(\mathrm{p}, \mathrm{d}, \mathrm{q})(\mathrm{P}, \mathrm{D}, \mathrm{Q})^{\mathrm{s}}$

Dimana :

$\mathrm{p}, \mathrm{d}, \mathrm{q} \quad$ : Bagian tidak musiman dari model

$(\mathrm{P}, \mathrm{D}, \mathrm{Q}) \quad$ : Bagian musiman dari model

$\mathrm{s} \quad$ : Jumlah periode per musim

Rumus umum dari SARIMA (p,d,q)(P,D,Q) ${ }^{\mathrm{s}}$ adalah sebagai berikut:

$\Phi_{\mathrm{p}} \mathrm{B}^{\mathrm{S}} \phi_{\mathrm{p}}(\mathrm{B})(1-B)^{\mathrm{d}}\left(1-\mathrm{B}^{\mathrm{S}}\right)^{\mathrm{D}} \mathrm{Z}_{\mathrm{t}}=\theta_{\mathrm{q}}(B) \Theta_{\mathrm{q}}\left(B^{\mathrm{S}}\right) \mathrm{a}_{\mathrm{t}}$

Dimana :

$\begin{array}{ll}{ }_{\mathrm{p}}^{\mathrm{B}} & : \text { AR Non Seasonal } \\ \Phi_{\mathrm{p}} \mathrm{B}^{\mathrm{S}} & \text { : AR Seasonal } \\ (1-B)^{d} & \text { : differencing non seasonal } \\ \left(1-B^{S}\right)^{D} & \text { : differencing seasonal } \\ \theta_{q}(\mathrm{~B}) & \text { : MA non seasonal } \\ \Theta_{q}\left(\mathrm{~B}^{\mathrm{S}}\right) & : \text { MA seasonal }\end{array}$

Bowerman and O`Connell (2018), dalam menetapkan nilai $\mathrm{p}$ dan $\mathrm{q}$ dapat dibantu dengan mengamati pola Autocorrelation Function (ACF) dan Partial Autocorrelation Function (PACF) dengan acuan pada tabel 2 . berikut:

Tabel 2. Pola Acf Dan Pacf Untuk Identifikasi Parameter Tentatif

\begin{tabular}{|c|c|c|}
\hline Model & Pola ACF & Pola PACF \\
\hline $\begin{array}{l}\text { ARMA } \\
(p, q)\end{array}$ & $\begin{array}{l}\text { Menurun secara } \\
\text { cepat (dies down) }\end{array}$ & $\begin{array}{l}\text { Menurun secara } \\
\text { cepat (dies down) }\end{array}$ \\
\hline $\begin{array}{l}\mathrm{AR}(\mathrm{p}) \\
\text { atau }\end{array}$ & $\begin{array}{l}\text { Muncul spike yang } \\
\text { signifikan hingga }\end{array}$ & $\begin{array}{l}\text { Muncul spike yang } \\
\text { signifikan lag ke-p }\end{array}$ \\
\hline MA (q) & $\begin{array}{l}\text { lag ke-q dan cut off } \\
\text { setelah lag ke-q }\end{array}$ & $\begin{array}{l}\text { dan cut off setelah } \\
\text { lag ke-p }\end{array}$ \\
\hline $\mathrm{AR}(\mathrm{p})$ & $\begin{array}{l}\text { Menurun secara } \\
\text { cepat (dies down) }\end{array}$ & $\begin{array}{l}\text { Muncul spike yang } \\
\text { signifikan } \\
\text { hingga lag ke-p } \\
\text { dan cut off } \\
\text { setelah lag ke-p }\end{array}$ \\
\hline MA (q) & $\begin{array}{l}\text { Muncul spike yang } \\
\text { signifikan } \\
\text { hingga lag ke-q } \\
\text { dan cut off } \\
\text { setelah lag ke-q }\end{array}$ & $\begin{array}{l}\text { Menurun secara } \\
\text { cepat (dies down) }\end{array}$ \\
\hline $\begin{array}{l}\text { AR }(p) \\
\text { atau }\end{array}$ & $\begin{array}{l}\text { Muncul spike yang } \\
\text { signifikan }\end{array}$ & $\begin{array}{l}\text { Muncul spike yang } \\
\text { signifikan }\end{array}$ \\
\hline MA (q) & $\begin{array}{l}\text { hingga lag ke-q } \\
\text { dan } \text { cut } \\
\text { setelah lag ke-q }\end{array}$ & $\begin{array}{l}\text { ingga lag ke-p } \\
\text { dan cut off } \\
\text { setelah lag ke-p }\end{array}$ \\
\hline
\end{tabular}

Tahapan pemeriksaan residual terbagi menjadi pemeriksaan L-jung Box (white noise), dan kenormalan residual. Pengujian untuk memenuhi asumsi white noise dilakukan pengujian L-jung Box dengan hipotesa :

$\mathrm{H}_{0}: \rho_{1}=\rho_{2}=\rho_{\ldots}=\rho_{k}=0$

$\mathrm{H}_{1}$ : minimal ada satu nilai $\rho_{k} \neq 0$, dimana $\mathrm{k}=$ $1,2, \ldots, \mathrm{K}$

dengan statistik uji :

$$
Q=n(n+2) \sum_{k=1}^{K}(n-k)^{-1} \hat{\rho}_{k}
$$

Dimana $\mathrm{n}$ adalah banyak pengamatan dan $\hat{\rho}_{k}$ adalah sampel ACF residual pada lag ke-k, dan $\mathrm{K}$ adalah lag maksimum. Daerah kritis $=\mathrm{Q}>x_{(a, K-m)}^{2}$ atau $P$-value $<\alpha=5 \%$.

Pengujian kenormalan distribusi dapat dilakukan uji Kolmogorov-Smirnov dengan hipotesa:

$\mathrm{H}_{0}$ : residual berdistribusi normal

$\mathrm{H}_{1}$ : residual tidak berdistribusi normal Dengan statistik uji :

$$
D={ }_{x}^{\operatorname{Sup}}\left[\left|F_{n}(x)-F_{0}(x)\right|\right]
$$

Dimana D adalah nilai deviasi absolut maksimum antara F (x) n dan ( ) $0 \mathrm{~F} \mathrm{x}$, Sup masing-masing merupakan fungsi Kolmogorov peluang kumulatif yang dihitung dari data sampel, fungsi peluang kumulatif distribusi normal, dan nilai supremum untuk semua $\alpha_{\mathrm{t}}$. Daerah Kritis: Tolak H0 jika $D \geq D_{(1-\alpha, \mathrm{n})}$ atau $P$-value $<\alpha$, dengan $\alpha=5 \%$. Model terbaik ditentukan berdasarkan nilai galat, semakin kecil nilai galat yang dihasilkan maka semakin baik model tersebut sekaligus menentukan model tersebut layak untuk digunakan pada peramalan.

\subsection{Single Exponential Smoothing}

Metode ini juga sering disebut perataan eksponensial tunggal yang biasa dipakai trader untuk peramalan jangka pendek. Model mengansumsikan jika data berfluktuasi di sekitar nilai mean yang tetap, dan juga tanpa trend atau pola pertumbuhan konsisten pada Biri, R., Langi, Y. A., \& Paendong, M. S. (2013). Tidak seperti Moving Average, Exponential Smoothing akan menawarkan penekanan yang lebih besar pada runtun waktu melalui penggunaan sebuah konstanta smoothing. Rumus dasarnya adalah:

$$
\mathrm{S}_{\mathrm{t}+1}=\left(a * X_{t}\right)+(1-\alpha) \mathrm{S}_{\mathrm{t}-1}
$$

a : Konstanta pemulusan

$\mathrm{t}$ : $\quad$ Periode waktu

Ada formula alternatif. Sebagai contoh, Roberts (1959) menggantikan yt-1 dengan pengamatan saat ini, y t. Rumus lain menggunakan ramalan untuk periode sebelumnya dan periode berjalan:

Dimana :

$$
F t=F_{t-1}+a\left(A_{t-1}-F_{t-1}\right)
$$

Ft-1 : Perkiraan untuk periode sebelumnya,

At-1 : Permintaan nilai aktual untuk periode tersebut, 
: Berat (harus antara 0 dan 1). Semakin dekat ke nol, semakin kecil bobotnya.

\subsection{Hybrid Metode}

Wiyanti et al. (2012), salah satu metode peramalan yang paling dikembangkan saat ini adalah runtun waktu, yakni menggunakan pendekatan kuantitatif dengan data masa lampau dikumpulkan dan dijadikan acuan untuk peramalan masa depan. Teknik peramalan time series terbagi menjadi dua bagian. Pertama, model peramalan yang didasarkan pada model matematika statistik seperti moving average, exponential smoothing, regresi, dan ARIMA (Box Jenkins). Kedua, model peramalan yang didasarkan pada kecerdasan buatan seperti neural network, algoritma genetika, simulated annealing, genetic programming, klasifikasi, dan hybrid. Dengan demikian kita mengetahui bahwa dalam time series forecasting, ilmu statistik dan jaringan syaraf pun termasuk dalam bidang kajian penelitiannya.

Zhang (2003), ada tiga hal yang menjadi alasan penggunaan pengkombinasian model peramalan. Pertama, sering kali terjadi kesulitan untuk menerapkan penggunaan model linier atau model non linier pada suatu permasalahan runtun waktu, sehingga model kombinasi ini menjadi alternatif yang lebih mudah. Kedua ,dalam kenyataannya runtun waktu jarang yang linier atau nonlinier dan sering mengandung keduanya, dimana tidak hanya model ARIMA dan Neural Network masing-masing dapat memodelkan setiap kasusnya, sehingga pengkombinasian ini dapat digunakan untuk memodelkan runtun waktu yang mengandung linier dan non linier. Ketiga, dalam beberapa literatur peramalan menyatakan bahwa tidak ada model tunggal yang terbaik pada setiap situasi. Cara mudah untuk meningkatkan akurasi ramalan adalah dengan menggabungkan beberapa metode berbeda pada seri waktu yang sama dan untuk merata-ratakan ramalan yang dihasilkan, menggabungkan metode peramalan sering kali menghasilkan akurasi prakiraan yang lebih baik.

\subsection{Evaluasi Hasil Peramalan}

Evaluasi hasil peramalan digunakan untuk mengetahui keakuratan hasil peramalan yang telah dilakukan terhadap data yang sebenarnya. Terdapat banyak metode untuk melakukan perhitungan kesalahan peramalan. Beberapa metode yang digunakan adalah :

Mean Absolute Deviation adalah ukuran kesalahan peramalan keseluruhan untuk sebuah model. Nilai MAD dihitung dengan mengambil jumlah nilai absolut dari kesalahan peramalan dibagi dengan jumlah periode data (n) [13].

$$
\begin{aligned}
& M A D=\frac{\sum \mid \text { data aktual }- \text { peramalan } \mid}{n} \\
& \text { dimana: } \\
& \mathrm{n}=\text { jumlah periode data }
\end{aligned}
$$

Mean Squared Error merupakan rata-rata selisih kuadrat antara nilai yang diramalkan dan yang diamati. Kekurangan penggunaan MSE adalah bahwa metode evaluasi ini cenderung menonjolkan nilai deviasi yang besar karena adanya pengkuadratan.

dimana:

$$
M S E=\frac{\sum(\text { kesalahan peramalan })^{2}}{n}
$$

$$
\mathrm{n}=\text { jumlah periode data }
$$

Mean Absolute Percentage Error adalah nilai ratarata dari selisih absolut antara nilai hasil peramalan dan nilai aktual, nilai ditunjukkan dalam persentase.

$$
\text { MAPE }=\sum_{t=1}^{T} \frac{\mid \text { peramalan }- \text { actual } \mid}{\text { aktual }} * 100
$$

\section{Metode}

\subsection{Metode Penelitian}

Metode yang digunakan dalam penelitian ini adalah:

1. SARIMA untuk peramalan deret waktu dengan akurasi yang baik untuk peramalan jangka menengah.

2. Single Exponential Smoothing akurat untuk peramalan dengan data yang berfluktuasi disekitar nilai rata rata yang tetap.

3. Penggabungan metode hybrid SARIMA-SES untuk peramalan dengan akurasi yang lebih baik dibandingkan menggunakan metode tunggal.

\subsection{Data Penelitian}

Data yang digunakan untuk penelitian ini adalah data inflasi tahun Januari 2011 - Desember 2017 dari Badan Pusat Statistik (BPS) dan data harga pangan yang digunakan berdasarkan rata-rata harga konsumen komoditas di Kota Bandung dari Portal Informasi Harga Pangan (Priangan).

\subsection{Tahap Penelitian}

Tahap penelitian yang akan dilakukan adalah sebagai berikut:

1. Pengumpulan data historis inflasi periode Januari 2011 - Desember 2017.

2. Identifikasi pola data dengan $\mathrm{ACF}$ dan $\mathrm{PACF}$ yang ditunjukkan oleh data.

3. Peramalan inflasi pelanggan dengan menggunakan metode :
a. SARIMA
b. Single Exponential Smoothing
c. Penggabungan metode hybrid SARIMA-SES

4. Membandingkan hasil peramalan dengan data aktual pada tahun 2018

5. Cek nilai error menggunakan MAD, MSE dan MAPE

6. Menghitung biaya hidup layak minimum (kapita/bulan) dari data hasil peramalan inflasi. 


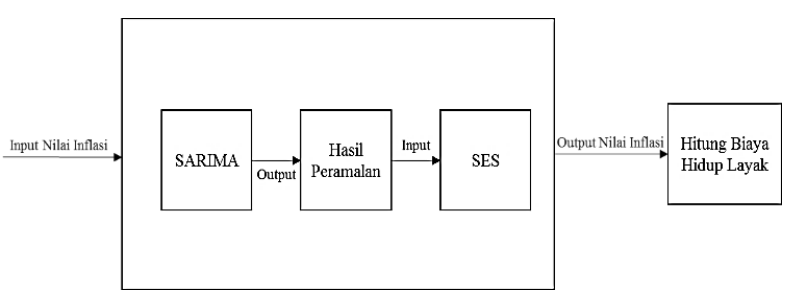

Gambar 1. Kerangka Sistem Peramalan

\subsection{Peramalan Menggunakan Metode SARIMA}

Berikut adalah proses peramalan menggunakan metode SARIMA yang terlihat pada Gambar 2 .

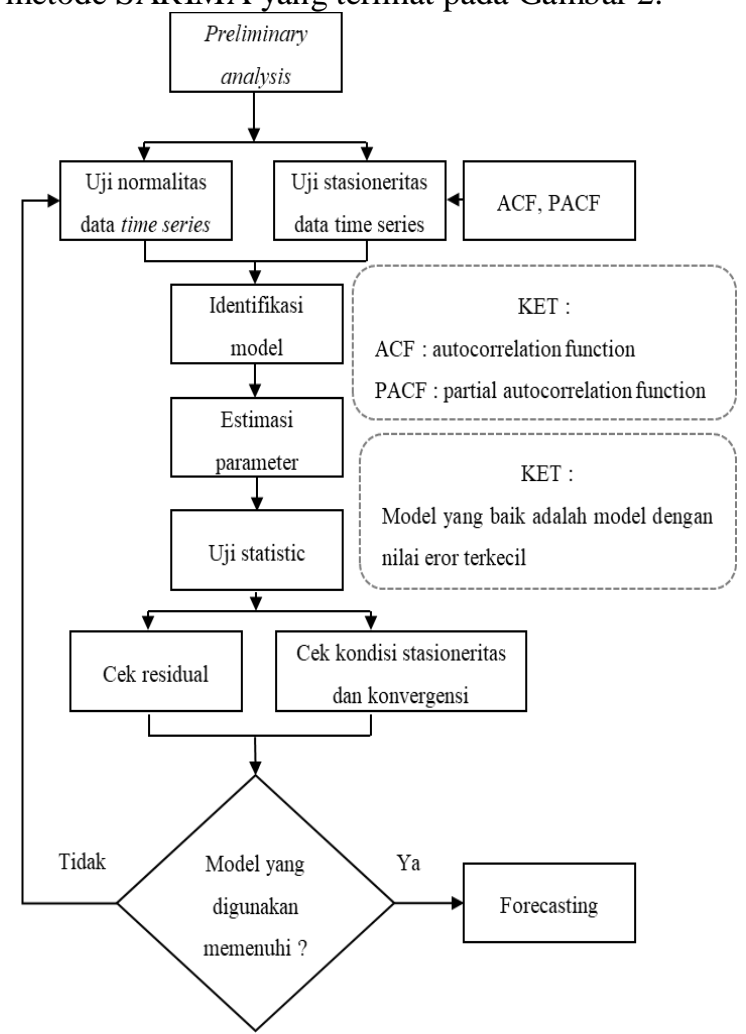

Gambar 2. Tahapan Metode SARIMA

\subsection{Peramalan Menggunakan Metode Single Exponential Smoothing}

Berikut adalah tahapan penggunaan metode Single Exponential Smoothing. Pada Gambar 3 adalah gambaran dari tahapan yang dilakukan dalam penggunaan metode Single Exponential Smoothing. Langkah-langkah peramalan dengan metode SES adalah menganalisis data, apakah stasioner dengan melihat pola yang terbentuk, kemudian data diramalkan menggunakan SES, kemudian membandingkan nilai error terkecil.

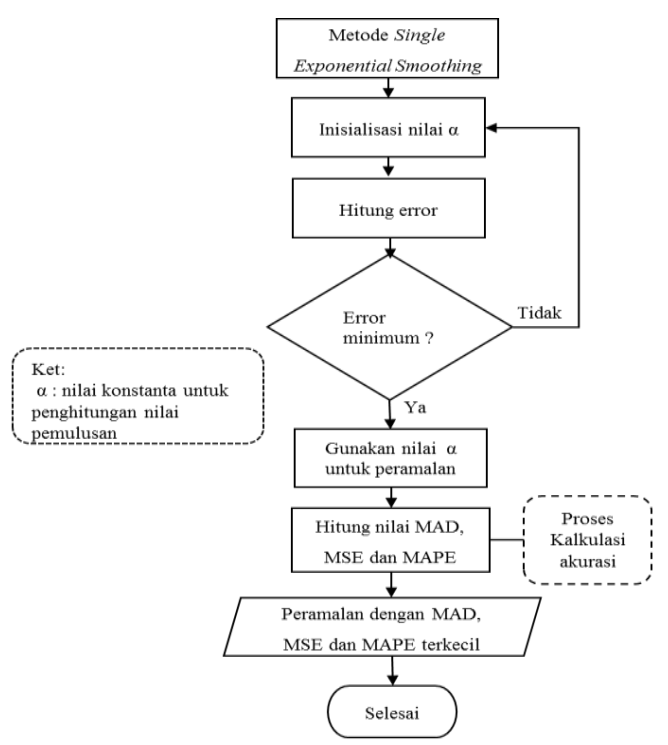

Gambar 3. Tahapan Metode Single Exponential Smoothing

\subsection{Peramalan Menggunakan Penggabungan Metode SARIMA dan Single Exponential Smoothing}

Berikut adalah tahapan hybrid metode SARIMA dan Single Exponential Smoothing. Pada gambar 2 ditunjukkan proses peramalan dengan menggunakan metode SARIMA. Pada tahap awal dilakukan analisa awal pola data, setelah itu dilakukan pengujian normalitas dan stasioneritas data historis. Pada tahap ini hasil pengujian ditunjukkan dengan ACF dan PACF. Setelah itu dilakukan uji statistik dengan parameter estimasi. Pengujian statistik tersebut menghasilkan independensi residual. Dari residual ini akan diperiksa independensi dan normalitasnya, sehingga akan diketahui model SARIMA yang digunakan baik atau tidak. Model SARIMA terbaik adalah model dengan nilai error terkcecil. Nilai error dalam penelitian ini didapatkan dengan menghitung nilai MAD, MSE dan MAPE.

Pada Gambar 4 adalah gambaran penggabungan metode SARIMA dan SES, tahapan awal data inflasi Kota Bandung akan diramalkan menggunakan metode SARIMA sesuai dengan langkah - langkah yang sudah dijelaskan sebelumnya. Model SARIMA dengan nilai error terkecil selanjutnya akan digunakan sebagai nilai inputan awal untuk metode SES, kemudian hasil peramalan dengan nilai error terkecil akan dikalkulasi dengan nilai KHL. Hasil kalkulasi tersebut adalah nilai KHL hasil peramalan berdasarkan nilai inflasi yang sudah diramalkan menggunakan metode gabungan SARIMA dan SES. 


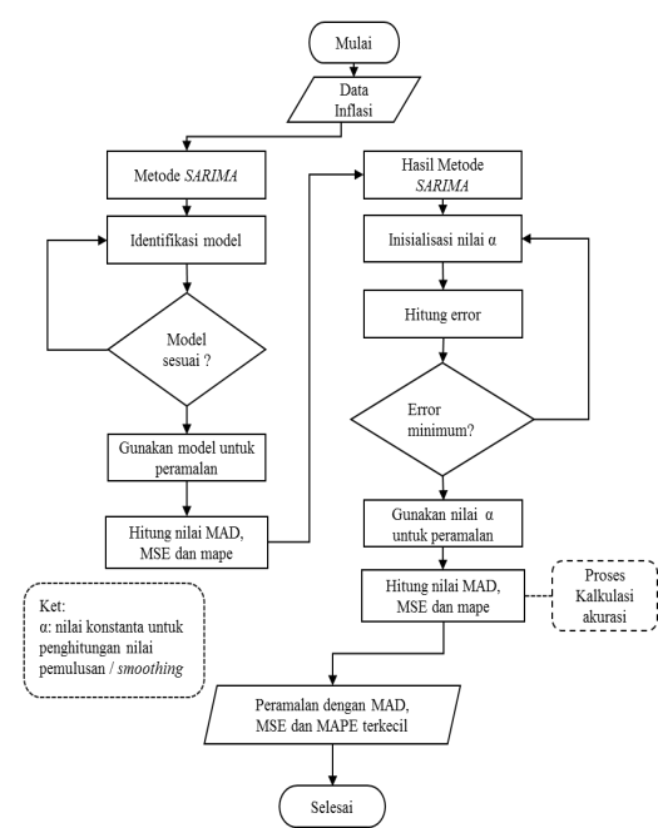

Gambar 4. Hybrid Metode SARIMA dan Single Exponential Smoohting

\section{Hasil dan Pembahasan}

\subsection{Peramalan Menggunakan Metode SARIMA}

Data yang digunakan dalam peramalan ini adalah data inflasi Kota Bandung berdasarkan IHK tahun 2011 - 2017 (Tabel 3). Data diambil dari Badan Pusat Statistik (BPS) Kota Bandung.

Tabel 3. Data Inflasi Januari 2011 - Desember 2017

\begin{tabular}{lccccccc}
\hline Inflasi & 2011 & 2012 & 2013 & 2014 & 2015 & 2016 & 2017 \\
\hline Januari & 0,32 & 1,24 & 0,64 & 1,09 & $-0,05$ & 0,53 & 0,49 \\
Februari & $-0,05$ & $-0,05$ & 1,03 & 0,39 & $-0,37$ & $-0,15$ & 0,38 \\
Maret & $-0,01$ & 0,05 & 0,64 & 0,11 & 0,61 & 0,21 & $-0,02$ \\
April & $-0,02$ & 0,18 & $-0,21$ & 0,05 & 0,43 & $-0,17$ & 0,11 \\
Mei & 0,12 & $-0,23$ & 0,34 & 0,19 & 0,28 & 0,24 & 0,47 \\
Juni & 0,17 & 0,55 & 1,29 & 0,21 & 0,72 & 0,64 & 0,99 \\
Juli & 0,51 & 1,07 & 3,11 & 0,75 & 0,85 & 0,71 & $-0,27$ \\
Agustus & 0,38 & 0,64 & 1,39 & 0,41 & 0,49 & 0,49 & 0,06 \\
September & $-0,21$ & 0,06 & $-0,49$ & 0,57 & $-0,01$ & 0,14 & 0,11 \\
Oktober & 0,19 & 0,34 & $-0,06$ & 0,14 & $-0,06$ & 0,14 & $-0,03$ \\
November & 0,47 & $-0,11$ & $-0,24$ & 1,27 & 0,19 & 0,52 & 0,39 \\
Desember & 0,85 & 0,19 & 0,33 & 2,34 & 0,78 & 0,64 & 0,73 \\
\hline
\end{tabular}

Pada Tabel 3 adalah data runtun waktu nilai inflasi Kota Bandung sebagai data awal untuk melakukan peramalan dalam penelitian ini. Langkah pertama yang dilakukan pada metode SARIMA adalah proses identifikasi model.

\section{1) Identifikasi Model:}

Proses identifikasi model data dilakukan dengan melihat plot data asli, sekaligus dilihat apakah data stasioner atau tidak dengan melihat plot ACF dan PACF.
Berdasarkan Bank Indonesia inflasi mengalami kenaikan ketika satu bulan sebelum hari raya idul fitri dan kemudian turun atau stabil ketika satu bulan setelah hari raya idul fitri. Hal ini dikarenakan adanya peningkataan volatille foods, akibat peningkatan konsumsi dan karena adanya ekspektasi masyarakat tentang kenaikan harga menjelang Hari Raya Idul Fitri. Pada Gambar 5 memperlihatkan bahwa data dipengaruhi pola musiman karena terjadi pengulangan pola pada periode tertentu (tahunan).

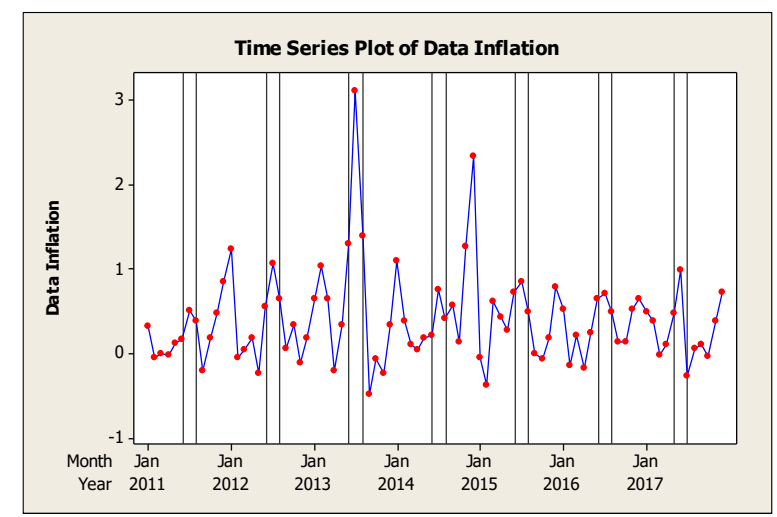

Gambar 5. Pola musiman data inflasi

Pada Gambar 6 memperlihatkan hasil proses transformasi data dengan Box-Cox Transformation. Data berstatus sudah stasioner terhadap ragam karena nilai Rounded Value pada Box-Cox plot sudah bernilai 1,00 .

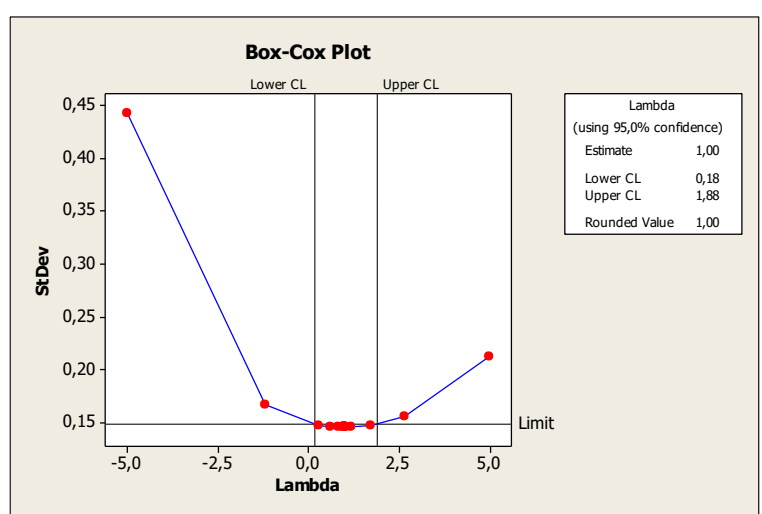

Gambar 6. Proses Box-Cox Transformation

Pada gambar 7 dan 8 memperlihatkan plot ACF dan PACF, dimana plot ACF dan PACF dapat digunakan untuk mengidentifikasi kandidat model yang sesuai untuk data inflasi Kota Bandung. Jika ACF dan PACF menunjukkan dies down yang artinya baik pola ACF ataupun pola PACF mengalami penurunan drastis pada setiap lag maka dapat dikatakan model SARIMA berupa gabungan AR dan MA. 


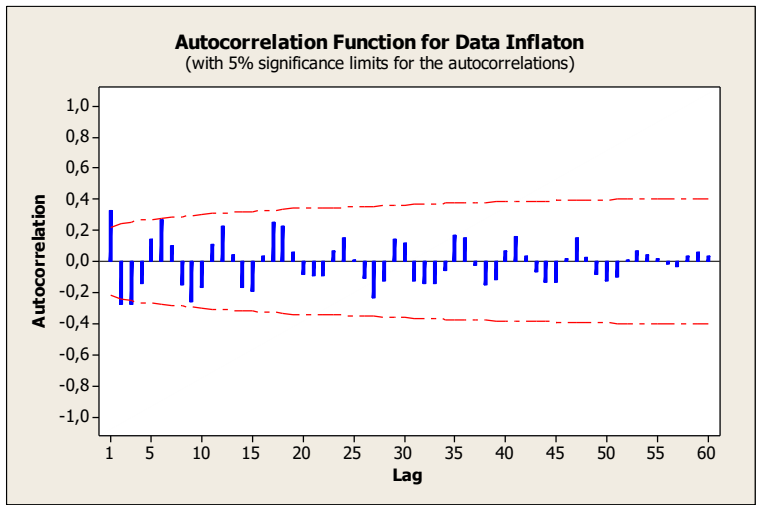

Gambar 7. Plot ACF

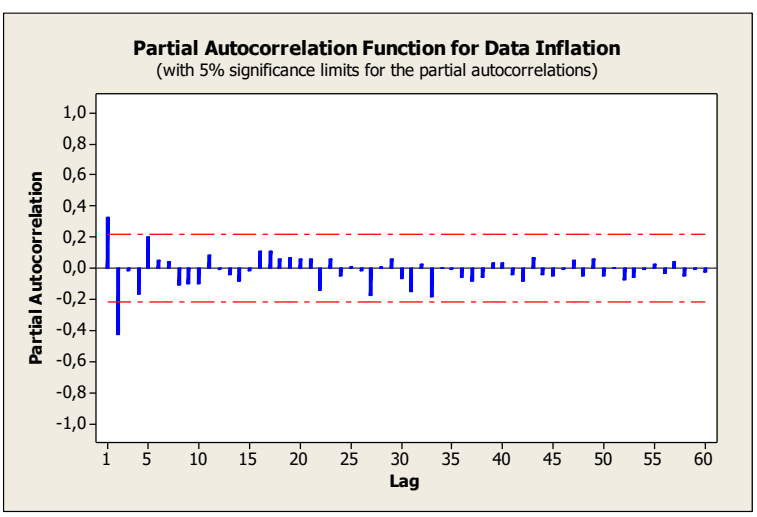

Gambar 8 Plot PACF

\section{2) Pendugaan Parameter:}

Kandidat model yang dihasilkan dari pendugaan sebelumnya dengan melihat pola ACF dan PACF yang menyatakan bahwa model adalah gabungan dari AR dan MA. Berikut adalah model yang dihasilkan oleh metode SARIMA terhadap pergerakan inflasi di Kota Bandung.

Tabel 4. Kandidat Model Sarima Data Inflasi

\begin{tabular}{lcccl}
\hline $\begin{array}{l}\text { Model SARIMA } \\
(\mathrm{p}, \mathrm{d}, \mathrm{q})(\mathrm{P}, \mathrm{D}, \mathrm{Q})^{12}\end{array}$ & MAD & MSE & MAPE & Keterangan \\
\hline $\begin{array}{l}\text { SARIMA } \\
(1,1,1)(1,1,0)^{12}\end{array}$ & 0,364 & 0,214 & $1,04 \%$ & $\begin{array}{l}\text { Tidak } \\
\text { Signifikan }\end{array}$ \\
$\begin{array}{l}\text { SARIMA } \\
(1,1,1)(1,1,1)^{12}\end{array}$ & 0,369 & 0,155 & $1,03 \%$ & $\begin{array}{l}\text { Tidak } \\
\text { Signifikan }\end{array}$ \\
$\begin{array}{l}\text { SARIMA } \\
(1,1,0)(1,1,0)^{12}\end{array}$ & 0,308 & 0,152 & $0,81 \%$ & $\begin{array}{l}\text { Tidak } \\
\text { Signifikan }\end{array}$ \\
$\begin{array}{l}\text { SARIMA } \\
(1,0,1)(1,1,1)^{12}\end{array}$ & 0,142 & 0,025 & $0,45 \%$ & Signifikan \\
$\begin{array}{l}\text { SARIMA } \\
(1,0,1)(1,0,1)^{12}\end{array}$ & 0,141 & 0,025 & $0,42 \%$ & Signifikan \\
\hline
\end{tabular}

Dari tabel 4 di atas dapat disimpulkan bahwa model SARIMA $(p, d, q)(P, D, Q)^{12}$ yang memenuhi syarat signifikansi adalah model SARIMA $(1,0,1)(0,0,1)^{12}$ dan SARIMA $(1,0,1)(1,1,1)^{12}$ karena semua parameternya signifikan ( nilai $\mathrm{P}<0,05$ ). Sedangkan model yang terbaik untuk data inflasi adalah SARIMA $(1,0,1)(1,0,1)^{12}$ karena memiliki nilai galat terkecil yaitu 0,141 untuk MAD, 0,025 untuk MSE dan $0,42 \%$ untuk MAPE. Hal ini menunjukkan bahwa model ini baik digunakan untuk peramalan.

\section{3) Pemeriksaan Residual:}

Setelah model SARIMA $(\mathrm{p}, \mathrm{d}, \mathrm{q})(\mathrm{P}, \mathrm{D}, \mathrm{Q})^{12}$ didapatkan kemudian dilakukan pemeriksaan residual yaitu uji white noise dan kenormalan residual pada model yang digunakan. Uji white noise pada metode SARIMA dilihat dari nilai L-jung Box (nilai Pr / Pvalue pada software minitab). Nilai $\mathrm{P}$-value pada setiap lag lebih besar daripada 0,05 sehingga dapat disimpulkan bahwa residual yang dihasilkan model SARIMA telah white noise.

Tabel 5. Uji white noise

\begin{tabular}{lllll}
\hline \multicolumn{4}{l}{ Modified Box-Pierce (Ljung-Box) } & Chi-Square statistic \\
\hline Lag & 12 & 24 & 36 & 48 \\
Chi-Square & 18,7 & 29,7 & 45,4 & 52, \\
& 9 & 21 & 33 & 45 \\
DF & 0,028 & 0,099 & 0,073 & 0,2 \\
P-Value & & & & 11 \\
& & & & \\
\hline
\end{tabular}

Untuk melihat apakah residual berdistribusi normal, dapat dilakukan dengan pengujian Kolmogorov-Smirnov dengan membandingkan distribusi data yang akan diuji normalitasnya dengan distribusi normal baku.

Pada gambar 9 dapat dilihat data terletak di sekitar garis lurus meskipun beberapa titik menyimpang cukup jauh dari garis lurus. Dengan demikian dapat diartikan bahwa residual sudah identik dan berdistribusi normal.

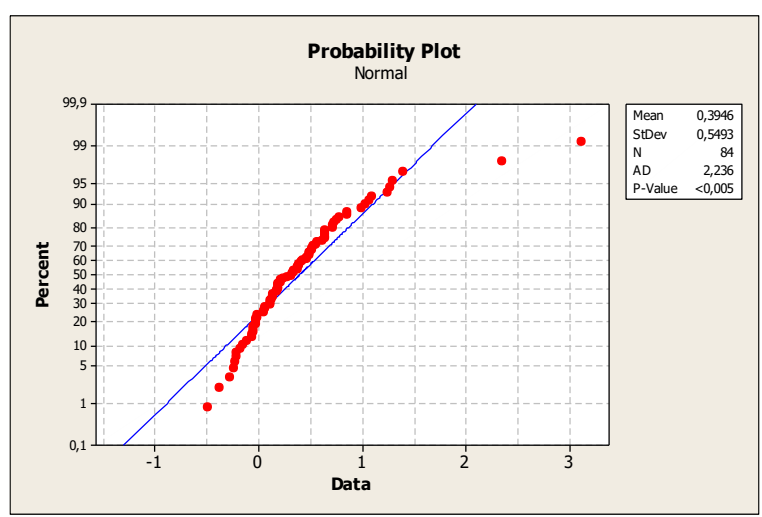

Gambar 9. Plot Normal Residual

4) Hasil Peramalan Metode SARIMA:

Berikut adalah hasil peramalan yang dihasilkan oleh metode SARIMA terhadap pergerakan inflasi pada tahun 2011 - 2017 di Kota Bandung.

Pada Tabel 6 memperlihatkan hasil peramalan dengan model SARIMA $(1,1,1)(0,1,1)^{12}$ untuk periode Januari 2018 - Juni 2018.

Tabel 6. Hasil Peramalan Metode Sarima 


\begin{tabular}{lccccc}
\hline $\begin{array}{c}\text { Periode } \\
2018\end{array}$ & $\begin{array}{c}\text { Nilai } \\
\text { Aktual } \\
\text { (a) }\end{array}$ & $\begin{array}{c}\text { Hasil } \\
\text { Peramalan } \\
(\mathrm{t})\end{array}$ & $\begin{array}{c}\text { Error } \\
\text { Absolut } \\
\left|\mathrm{A}_{\mathrm{t}}-\mathrm{F}_{\mathrm{t}}\right|\end{array}$ & $\begin{array}{c}\text { Square } \\
\text { Of Error } \\
\mid(\text { At }-\mathrm{Ft})^{2} \mid\end{array}$ & $\begin{array}{c}\text { Absolute } \\
\text { Values } \\
\text { Of Errors } \\
\mid(\text { At }- \\
\text { Ft }) / \mathrm{At} \mid\end{array}$ \\
\hline Jan & 0,83 & 0.68 & 0.15 & 0.021 & 0.18 \\
Feb & 0,22 & 0.30 & -0.08 & 0.006 & 0.35 \\
Mar & 0,21 & 0.17 & 0.04 & 0.002 & 0.21 \\
Apr & 0,27 & 0.09 & 0.18 & 0.033 & 0.67 \\
Mei & 0,22 & 0.34 & -0.12 & 0.014 & 0.54 \\
Jun & 0,48 & 0.76 & -0.28 & 0.076 & 0.57 \\
\hline \multirow{2}{*}{ Nilai Error } & & & MAD & MSE & MAPE \\
\hline
\end{tabular}

\begin{tabular}{cccc}
\hline Alpha $(a)$ & MAD & MSE & MAPE \\
\hline 0,1 & 0,161 & 0,059 & $0.32 \%$ \\
0,2 & 0,204 & 0,079 & $0.45 \%$ \\
0,3 & 0,206 & 0,073 & $0.48 \%$ \\
0,4 & 0,217 & 0,073 & $0.55 \%$ \\
0,5 & 0,167 & 0,063 & $0.35 \%$ \\
0,6 & 0,224 & 0,071 & $0.63 \%$ \\
0,7 & 0,230 & 0,070 & $0.69 \%$ \\
0,8 & 0,237 & 0,071 & $0.75 \%$ \\
0,9 & 0,244 & 0,072 & $0.80 \%$ \\
\hline
\end{tabular}

Gambar 10 adalah gambar grafik perbandingan nilai aktual dan model SARIMA $(1,0,1)(1,0,1)^{12}$ dengan nilai error terkecil yaitu MAD 0,141, MSE 0,025 dan MAPE $0,42 \%$ untuk peramalan periode Januari 2018 - Juni 2018.



Gambar 10. Grafik Perbandingan data aktual dan SARIMA

\subsection{Peramalan Menggunakan Metode Single Exponential Smoothing}

Dari data inflasi bulanan periode Januari 2011 Desember 2017, akan diramalkan model yang cocok untuk metode SES dengan melihat hasil peramalan yang dibandingkan dengan nilai aktual.

1) Penentuan Model Single Exponential Smoothing:

Langkah-langkah peramalan dengan metode SES adalah menganalisis data, kemudian data diramalkan dengan menentukan nilai alpha yang cocok untuk dijadikan model peramalan. Kemudian membandingkan manakah nilai error terkecil, penentuan metode yang tepat dilakukan secara trial and error yakni nilai parameter diubah-ubah hingga didapat eror terkecil.

Pada Tabel 7 dapat dilihat model Single Exponential Smoothing dengan nilai error MAD, MSE dan MAPE terkecil terdapat pada model alpha 0,1 dengan nilai MAD 0,161, MSE 0,059 dan MAPE $0,32 \%$.

2) Hasil Peramalan Metode Single Exponential Smoothing:

Berikut adalah hasil peramalan yang dihasilkan oleh metode Single Exponential Smoothing terhadap pergerakan inflasi pada tahun 2011 - 2017 di Kota Bandung.

Tabel 8 memperlihatkan hasil peramalan dengan model SES dengan nilai alpha 0,1 untuk periode Januari 2018 - Juni 2018 dengan nilai MAD 0,161, MSE 0,059 dan MAPE 0,32\%.

Tabel 8. Hasil Peramalan Metode SES

\begin{tabular}{llllll}
\hline $\begin{array}{l}\text { Perio } \\
\text { de } \\
2018\end{array}$ & $\begin{array}{l}\text { Nilai } \\
\text { Aktual } \\
\text { (a) }\end{array}$ & $\begin{array}{l}\text { Hasil } \\
\text { Peramalan } \\
\text { (t) }\end{array}$ & $\begin{array}{l}\text { Error } \\
\text { Absolut } \\
\left|\mathrm{A}_{\mathrm{t}}-\mathrm{F}_{\mathrm{t}}\right|\end{array}$ & $\begin{array}{l}\text { Square } \\
\text { Of Error } \\
(\text { ( At -Ft })^{2} \mid\end{array}$ & $\begin{array}{l}\text { Absolute } \\
\text { Values } \\
\text { Of Errors } \\
\mid(\text { At }-\mathrm{Ft}) / \mathrm{At} \mid\end{array}$ \\
\hline Jan & 0,83 & 0,32 & 0.51 & 0.2607 & 0.62 \\
$\mathrm{Feb}$ & 0,22 & 0,29 & 0.07 & 0.0046 & 0.31 \\
Mar & 0,21 & 0,26 & 0.05 & 0.0024 & 0.23 \\
Apr & 0,27 & 0,23 & 0.04 & 0.0014 & 0.14 \\
Mei & 0,22 & 0,21 & 0.01 & 0.0001 & 0.05 \\
Jun & 0,48 & 0,19 & 0.29 & 0.0849 & 0.61 \\
\hline \multirow{2}{*}{ Nilai Error } & & MAD & MSE & MAPE \\
\hline
\end{tabular}

Gambar 11 adalah gambar grafik perbandingan nilai aktual dan model SES dengan nilai alpha 0,1 untuk periode Januari 2018 - Juni 2018 dengan nilai error terkecil yaitu MAD 0,161, MSE 0,059 dan MAPE 0,32\%.



Gambar 11. Grafik perbandingan data aktual dan SES 


\subsection{Peramalan Menggunakan Metode Hybrid SARIMA-SES}

Tahapan ini adalah tahap untuk memodelkan nilai Single Exponential Smoothing dari model SARIMA. Oleh karena itu tahap ini disebut sebagai tahapan penggabungan, hasil ramalan dari metode SARIMA kemudian dijadikan data input untuk model Single Exponential Smoothing. Secara matematis, hasil ramalan secara keseluruhan yang diperoleh adalah sebagai berikut.

\section{1) Hasil Peramalan Metode SARIMA:}

Dari hasil peramalan metode SARIMA sebelumnya, didapatkan model SARIMA yang terbaik untuk data inflasi adalah model SARIMA $(1,0,1)(1,0,1)^{12}$ karena memiliki nilai galat terkecil yaitu 0,141 untuk MAD, 0,025 untuk MSE dan 0,42\% untuk MAPE.

Tabel 9. Hasil Peramalan Metode SARIMA

\begin{tabular}{lccccc}
\hline $\begin{array}{c}\text { Periode } \\
2018\end{array}$ & $\begin{array}{c}\text { Nilai } \\
\text { Aktual } \\
(\mathrm{a})\end{array}$ & $\begin{array}{c}\text { Hasil } \\
\text { Peramalan } \\
(\mathrm{t})\end{array}$ & $\begin{array}{c}\text { Error } \\
\text { Absolut } \\
\left|\mathrm{A}_{\mathrm{t}}-\mathrm{F}_{\mathrm{t}}\right|\end{array}$ & $\begin{array}{c}\text { Square } \\
\text { Of Error } \\
\mid(\text { At }-\mathrm{Ft})^{2} \mid\end{array}$ & $\begin{array}{c}\text { Absolute } \\
\text { Values } \\
\text { Of Errors } \\
\mid \text { (At -Ft)/At } \mid\end{array}$ \\
\hline Jan & 0,83 & 0.68 & 0.15 & 0.021 & 0.18 \\
Feb & 0,22 & 0.30 & -0.08 & 0.006 & 0.35 \\
Mar & 0,21 & 0.17 & 0.04 & 0.002 & 0.21 \\
Apr & 0,27 & 0.09 & 0.18 & 0.033 & 0.67 \\
Mei & 0,22 & 0.34 & -0.12 & 0.014 & 0.54 \\
Jun & 0,48 & 0.76 & -0.28 & 0.076 & 0.57 \\
\hline \multirow{2}{*}{ Nilai Error } & & & MAD & MSE & MAPE \\
\hline \multicolumn{5}{r}{} \\
\end{tabular}
digunakan untuk peramalan dan dapat dijadikan data input untuk model Single Exponential Smoothing.

2) Hasil Peramalan Metode Hybrid SARIMA-SES:

Dari hasil peramalan metode SARIMA, nilai inflasi hasil peramalan akan dijadikan nilai inputan untuk peramalan menggunakan metode Single Exponential Smoothing.

Pada tabel 10 dapat dilihat model Single Exponential Smoothing dengan nilai error MAD, MSE dan MAPE terkecil terdapat pada model alfa 0,6 dengan nilai MAD 0,114, MSE 0,017 dan MAPE $0,39 \%$.

Tabel 10. Penentuan nilai alpha

\begin{tabular}{cccc}
\hline Alpha $(a)$ & MAD & MSE & MAPE \\
\hline 0,1 & 0,259 & 0,086 & $1.05 \%$ \\
0,2 & 0,199 & 0,054 & $0.81 \%$ \\
0,3 & 0,156 & 0,036 & $0.62 \%$ \\
0,4 & 0,118 & 0,025 & $0.46 \%$ \\
0,5 & 0,115 & 0,019 & $0.40 \%$ \\
0,6 & 0,114 & 0,017 & $0.39 \%$ \\
0,7 & 0,116 & 0,018 & $0.40 \%$ \\
0,8 & 0,120 & 0,025 & $0,42 \%$ \\
0,9 & 0,151 & 0,028 & $0,43 \%$ \\
\hline
\end{tabular}

Tabel 11 memperlihatkan hasil peramalan dengan penggabungan metode SARIMA $(1,0,1)(1,0,1){ }^{12}$ dan metode Single Exponential Smoothing dengan nilai alpha 0,6 untuk periode Januari 2018 - Juni 2018 dengan nilai error MAD 0,114, MSE 0,0,17 dan MAPE $0,39 \%$.

Tabel 11.hasil Peramalan Metode Hybrid SARIMASES

\begin{tabular}{lccccc}
\hline $\begin{array}{c}\text { Periode } \\
2018\end{array}$ & $\begin{array}{c}\text { Nilai } \\
\text { Aktual } \\
(\mathrm{a})\end{array}$ & $\begin{array}{c}\text { Hasil } \\
\text { Peramalan } \\
(\mathrm{t})\end{array}$ & $\begin{array}{c}\text { Error } \\
\text { Absolut } \\
\left|\mathrm{A}_{\mathrm{t}}-\mathrm{F}_{\mathrm{t}}\right|\end{array}$ & $\begin{array}{c}\text { Square } \\
\text { Of Error } \\
(\text { At }-\mathrm{Ft})^{2} \mid\end{array}$ & $\begin{array}{c}\text { Absolute } \\
\text { Values } \\
\text { Of Errors } \\
(\text { At -Ft }) / \mathrm{At} \mid\end{array}$ \\
\hline Jan & 0,83 & 0.68 & 0.15 & 0,01 & 0.18 \\
Feb & 0,22 & 0.45 & 0.23 & 0,03 & 1.05 \\
Mar & 0,21 & 0.28 & 0.07 & 0,01 & 0.33 \\
Apr & 0,27 & 0.16 & 0.11 & 0,03 & 0.39 \\
Mei & 0,22 & 0.27 & 0.05 & 0,02 & 0.23 \\
Jun & 0,48 & 0.56 & 0.08 & 0,10 & 0.17 \\
\hline Nilai Error & & & MAD & MSE & MAPE \\
\hline
\end{tabular}

Gambar 12 adalah gambar grafik perbandingan nilai aktual dan model penggabungan metode SARIMA $(1,0,1)(1,0,1) 12$ dan SES dengan nilai alpha 0,1 untuk periode Januari 2018 - Juni 2018 dengan nilai error terkecil yaitu MAD 0,114, MSE 0,0,17 dan MAPE 0,39\%. Penggabungan metode SARIMA dan SES menghasilkan nilai error yang lebih kecil dibandingkan dengan penggunaan metode tunggal.

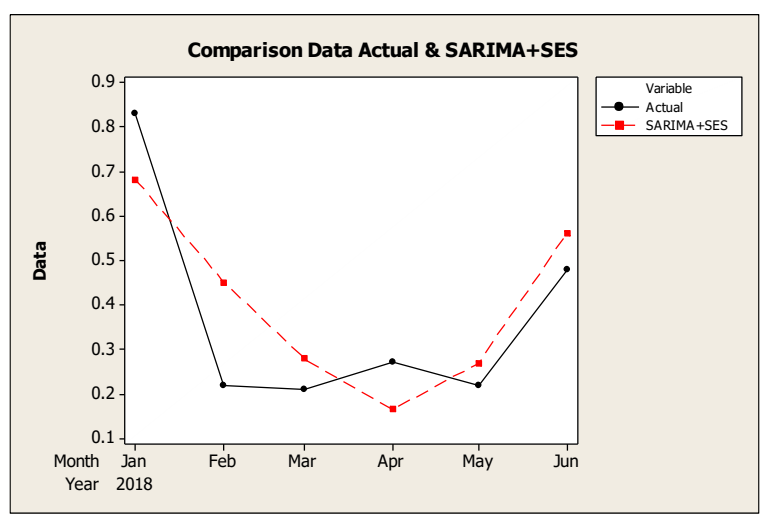

Gambar 12. Grafik perbandingan data aktual dan Metode Hybrid

\section{3) Perbandingan Nilai Error:}

Berikut adalah perbandingan nilai error peramalan yang dihasilkan oleh metode SARIMA, metode Single Exponential Smoothing dan Hybrid SARIMA-SES terhadap pergerakan inflasi pada tahun 2011 - 2017 di Kota Bandung. 
Pada tabel 12 diperlihatkan bahwa hasil metode Hybrid SARIMA-SES lebih baik dibandingkan dengan menggunakan metode tunggal. Dilihat dari nilai MAD, MSE dan MAPE yang lebih kecil jika dibandingkan dengan nilai MAD, MSE dan MAPE dari kedua model lainnya, dengan nilai MAD 0,141, MSE 0,017 dan 0,39\% untuk MAPE. Berikut adalah grafik perbandingan nilai aktual, metode SARIMA, metode Single Exponential Smoothing dan metode Hybrid SARIMA-SES.

Tabel 12. Perbandingan Nilai Error

\begin{tabular}{lcccc}
\hline $\begin{array}{c}\text { Periode } \\
2018\end{array}$ & $\begin{array}{c}\text { Aktu } \\
\text { al }\end{array}$ & SARIMA & $\begin{array}{c}\text { Single } \\
\text { Exponential } \\
\text { Smoothing }\end{array}$ & $\begin{array}{c}\text { SARIMA } \\
+ \text { SES }\end{array}$ \\
\hline Jan & 0,83 & 0.68 & 0,32 & 0.68 \\
Feb & 0,22 & 0.30 & 0,29 & 0.45 \\
Mar & 0,21 & 0.17 & 0,26 & 0.28 \\
Apr & 0,27 & 0.09 & 0,23 & 0.16 \\
Mei & 0,22 & 0.34 & 0,21 & 0.27 \\
Jun & 0,48 & 0.76 & 0,19 & 0.56 \\
& & MAD & MAD & MAD \\
& & 0,141 & 0,161 & 0,114 \\
Nilai Error & MSE & MSE & MSE \\
& & 0,025 & 0,059 & 0,017 \\
& & MAPE & MAPE & MAPE \\
& & $0,42 \%$ & $0,32 \%$ & $0,39 \%$ \\
\hline
\end{tabular}

Pada Gambar 13 adalah gambar grafik perbandingan nilai inflasi aktual, nilai inflasi hasil peramalan SARIMA, nilai inflasi hasil peramalan Single Exponential Smoothing dan nilai inflasi hasil metode Hybrid SARIMA-SES. Dapat dilihat jika nilai error yang dihasilkan oleh metode Hybrid SARIMASES memiliki nilai error yang lebih kecil dibandingkan dengan menggunakan metode tunggal.

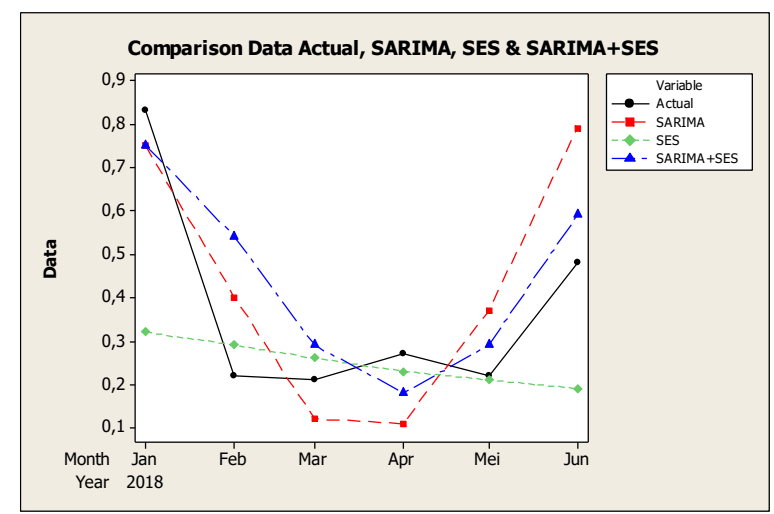

Gambar 13. Grafik perbandingan data aktual,

SARIMA,Single Exponential Smoothing dan Hybrid SARIMA \& SES

\subsection{Kebutuhan Hidup Layak}

Kebutuhan hidup layak adalah standar kebutuhan hidup seorang pekerja/buruh lajang untuk dapat hidup secara fisik dalam satu bulan. Ada 60 item yang dihitung dalam HKL yang dikelompokan didalam 7 komponen, diantranya : makanan dan minuman (11 item), sandang (13 item), perumahan (26 item), pendidikan ( 2 item), kesehatan (5 item), transportasi
(1 item), rekreasi dan tabungan (2 item). Akan tetapi dalam penelitian ini akan penulis lebih memfokuskan pada komponen makanan dan minuman dengan 11 item. Data tentang pangan didapatkan dari rata-rata harga konsumen komoditas di Kota Bandung dari Portal Informasi Harga Pangan.

Tabel 13 memperlihatkan data pangan bulan Desember 2017 di Kota Bandung dengan 11 item yang ditetapkan Keputusan Menteri Tenaga Kerja No. 13 tahun 2012

Tabel 13.Standar KHL Periode Desember 2017 Berdasarkan Komponen Makanan dan Minuman

\begin{tabular}{|c|c|c|c|c|}
\hline No. & Komponen & Kualitas & Jumlah & Harga \\
\hline 1 & Beras Sedang & Sedang & $10 \mathrm{~kg}$ & Rp126,240 \\
\hline 2 & $\begin{array}{l}\text { Sumber Protein : } \\
\text { a. Daging } \\
\text { b. Ikan Segar } \\
\text { c. Telur Ayam }\end{array}$ & $\begin{array}{l}\text { Sedang } \\
\text { Baik } \\
\text { Baik }\end{array}$ & $\begin{array}{l}0.75 \mathrm{~kg} \\
1.2 \mathrm{~kg} \\
1 \mathrm{~kg}\end{array}$ & $\begin{array}{l}\text { Rp84,083 } \\
\text { Rp85,082 } \\
\text { Rp20,623 }\end{array}$ \\
\hline 3 & $\begin{array}{l}\text { Kacang-kacangan : } \\
\text { tempe/tahu }\end{array}$ & Baik & $4.5 \mathrm{~kg}$ & Rp51,156 \\
\hline 4 & Susu bubuk & Sedang & $0.9 \mathrm{~kg}$ & Rp32,940 \\
\hline 5 & Gula pasir & Sedang & $3 \mathrm{~kg}$ & $\mathrm{Rp} 40,104$ \\
\hline 6 & Minyak goreng & Curah & $2 \mathrm{~kg}$ & Rp23,168 \\
\hline 7 & Sayuran & Baik & $7.2 \mathrm{~kg}$ & Rp72,000 \\
\hline 8 & $\begin{array}{l}\text { Buah-buahan (setara } \\
\text { pisang/pepaya) }\end{array}$ & Baik & $7.5 \mathrm{~kg}$ & Rp70,500 \\
\hline 9 & Karbohidrat lain & Sedang & $3 \mathrm{~kg}$ & $\mathrm{Rp} 45,000$ \\
\hline 10 & Teh atau Kopi & Celup/Sachet & 2 Dus isi & Rp11,000 \\
\hline 11 & Bumbu-bumbuan & Nilai $1-10$ & $1 \mathrm{~kg}$ & Rp35,700 \\
\hline Total & & & & Rp697,596 \\
\hline
\end{tabular}

\section{1) KHL Berdasarkan Hasil Peramalan Inflasi SARIMA:}

Berikut adalah nilai KHL yang dihasilkan oleh hasil kalkulasi dengan nilai inflasi yang diramalkan menggunakan metode SARIMA. Nilai awal KHL diambil dari nilai KHL pada bulan Desember 2017.

Tabel 14 adalah hasil peramalan nilai KHL berdasarkan hasil kalkulasi dengan nilai inflasi yang dihasilkan oleh peramalan SARIMA

Tabel 14. KHL Berdasarkan Nilai Inflasi SARIMA

\begin{tabular}{lccc}
\hline \multirow{2}{*}{$\begin{array}{c}\text { Periode } \\
2018\end{array}$} & \multicolumn{3}{c}{$\begin{array}{c}\text { Kebutuhan Hidup Layak } \\
\text { (Minumim/Bulan/Kapita) }\end{array}$} \\
\cline { 2 - 4 } & Aktual KHL & \multicolumn{2}{c}{ SARIMA } \\
\hline Jan & Rp 686,665 & 0.68 & Rp 687,572 \\
Feb & Rp 690,973 & 0.30 & Rp 690,249 \\
Mar & Rp 691,421 & 0.17 & Rp 691,157 \\
Apr & Rp 687,742 & 0.09 & Rp 691,696 \\
Mei & Rp 691,121 & 0.34 & Rp 689,957 \\
Jun & Rp 689,053 & 0.76 & Rp 687,074 \\
\hline
\end{tabular}

Gambar 14 menunjukan grafik perbandingan nilai KHL aktual dan KHL berdasarkan akumulasi nilai inflasi yang dihasilkan oleh peramalan SARIMA. 




Gambar 14. Grafik Perbandingan KHL Aktual dan KHL SARIMA

2) KHL Berdasarkan Hasil Peramalan Inflasi SES: Berikut adalah nilai KHL yang dihasilkan oleh hasil kalkulasi dengan nilai inflasi yang diramalkan menggunakan metode Single Exponential Smoothing (Tabel 15)..

Tabel 15. KHL berdasarkan nilai SES

\begin{tabular}{lccc}
\hline \multirow{2}{*}{$\begin{array}{c}\text { Periode } \\
\text { 2018 }\end{array}$} & \multicolumn{3}{c}{$\begin{array}{c}\text { Kebutuhan Hidup Layak } \\
\text { (Minumim/Bulan/Kapita) }\end{array}$} \\
\cline { 2 - 4 } & Aktual KHL & \multicolumn{2}{c}{ SES } \\
\hline Januari & Rp 686,665 & 0,32 & Rp 690,095 \\
Februari & Rp 690,973 & 0,29 & Rp 690,316 \\
Maret & Rp 691,421 & 0,26 & Rp 690,515 \\
April & Rp 687,742 & 0,23 & Rp 690,694 \\
Mei & Rp 691,121 & 0,21 & Rp 690,855 \\
Juni & Rp 689,053 & 0,19 & Rp 691,000 \\
\hline
\end{tabular}

Pada Tabel 15 adalah hasil peramalan nilai KHL berdasarkan hasil kalkulasi dengan nilai inflasi yang dihasilkan oleh peramalan Single Exponential Smoothing.

Gambar 15 menunjukan grafik perbandingan nilai KHL aktual dan KHL berdasarkan akumulasi nilai inflasi yang dihasilkan oleh peramalan SARIMA

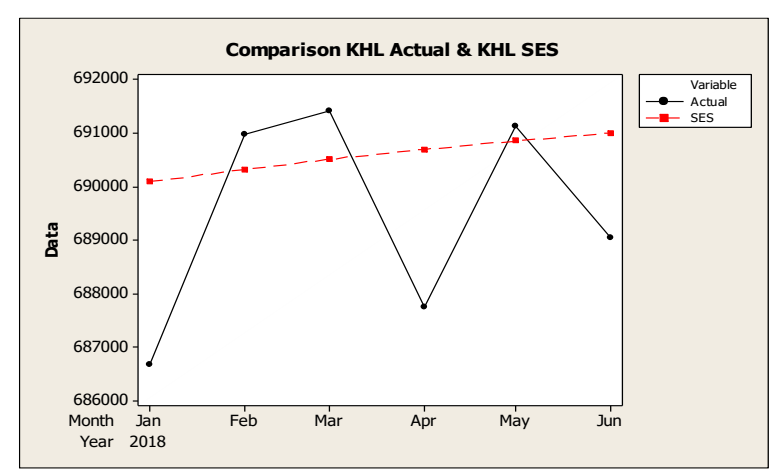

Gambar 15. Grafik Perbandingan KHL Aktual dan KHL SES
3) KHL Berdasarkan Hasil Peramalan Inflasi Hybrid SARIMA-SES:

Berikut adalah nilai KHL yang dihasilkan oleh hasil kalkulasi dengan nilai inflasi yang diramalkan menggunakan metode Hybrid SARIMA-SES (Tabel 16).

Tabel 16. KHL berdasarkan nilai inflasi HYBRID SARIMA-SES

\begin{tabular}{|c|c|c|c|}
\hline \multirow{3}{*}{$\begin{array}{c}\text { Periode } \\
2018\end{array}$} & \multicolumn{3}{|c|}{$\begin{array}{l}\text { Kebutuhan Hidup Layak } \\
\text { (Minumim/Bulan/Kapita) }\end{array}$} \\
\hline & \multirow{2}{*}{ Aktual KHL } & \multicolumn{2}{|c|}{ Hybrid SARIMA-SES } \\
\hline & & Inflasi & KHL \\
\hline Januari & Rp 686,665 & 0.68 & $\operatorname{Rp} 687,583$ \\
\hline Februari & Rp 690,973 & 0.45 & Rp 689,182 \\
\hline Maret & Rp 691,421 & 0.28 & Rp 690,367 \\
\hline April & Rp 687,742 & 0.16 & Rp 691,164 \\
\hline Mei & $\operatorname{Rp} 691,121$ & 0.27 & $\operatorname{Rp} 690,440$ \\
\hline Juni & Rp 689,053 & 0.56 & $\operatorname{Rp} 688,421$ \\
\hline
\end{tabular}

Tabel 16 adalah hasil peramalan nilai KHL berdasarkan hasil kalkulasi dengan nilai inflasi yang dihasilkan oleh peramalan Hybrid SARIMA-SES.

Gambar 16 menunjukan grafik perbandingan nilai KHL aktual dan KHL berdasarkan akumulasi nilai inflasi yang dihasilkan oleh peramalan metode Hybrid SARIMA- SES. Berikut adalah grafik perbandingan nilai KHL berdasarkan hasil kalkulasi dengan hasil peramlana nilai inflasi

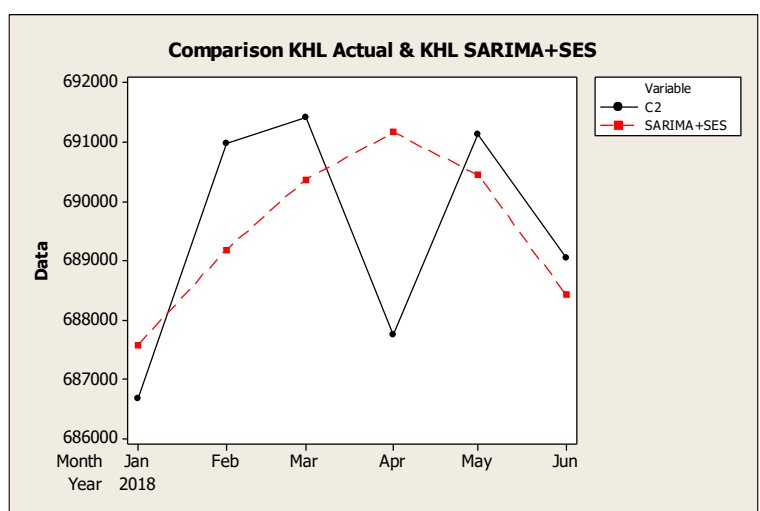

Gambar 16. Grafik Perbandingan KHL Aktual dan KHL Hybrid SARIMA- SES

Gambar 17 adalah gambar grafik perbandingan nilai kebutuhan hidup layak aktual, nilai kebutuhan hidup layak hasil kalkulasi dengan nilai inflasi peramalan SARIMA, nilai inflasi hasil peramalan Single Exponential Smoothing dan nilai inflasi hasil metode Hybrid SARIMA-SES. 




Gambar 17. Grafik Perbandingan Nilai KHL

\section{Kesimpulan}

Penggunaan metode Hybrid SARIMA-SES untuk peramalan nilai inflasi Kota Bandung menghasilkan nilai peramalan yang lebih akurat dibandingkan menggunakan metode tunggal, dengan nilai error MAD 0,114, MSE 0,017 dan MAPE 0,39\%. Sehingga hasil implementasi peramalan nilai inflasi Kota Bandung untuk periode berikutnya dapat dijadikan acuan untuk perhitungan perkiraan nilai kebutuhan hidup layak. Hasil perhitungan nilai kebutuhan hidup layak berdasrkan kalkulasi dengan nilai inflasi memiliki hasil yang sangat baik karena mendekati nilai aktual kebutuhan hidup layak untuk kategori makanan dan minuman. Hasil perhitungan kebutuhan hidup layak juga dapat dijadikan acuan untuk memperkirakan cukup atau tidak seorang pekerja lajang untuk memenuhi kebutuhan hidupnya selama satu bulan, dalan kasus ini menyangkut biaya untuk makanan dan minuman selama satu bulan di Kota Bandung.

\section{Ucapan Terimakasih}

Saya ingin mengucapkan terima kasih yang tulus kepada Kementrian Riset, Teknologi dan Pendidikan Tinggi Republik Indonesia atas program Hibah Penelitian Tesis Magister dengan nomor kontrak: No. 2898 / LA / PP / 2019.
Biri, R., Langi, Y.A., \& Paendong, M.S., 2013. Penggunaan Metode Smoothing Eksponensial dalam Meramal Pergerakan Inflasi Kota Palu. Jurnal Ilmiah Sains, 13(1), 68-73.

Bowerman, B.L. and O'Connell, R.T., 2018. Forecasting and time series : an applied approach / Bruce L. Bowerman, Richard T. O`Connell.

Peraturan Menteri Tenaga Keja dan Transmigrasi RI No. 13 Tahun 2012 tentang Komponen dan Pelaksanaan Tahapan Pencapaian Kebutuhan Hidup layak.

Peraturan Menteri Tenaga Keja dan Transmigrasi RI No. 17 Tahun 2005 tentang Komponen dan Pelaksanaan Tahapan Pencapaian Kebutuhan Hidup layak.

Peraturan Pemerintah Nomor 78 Tahun 2015 tentang Pengupahan.

Pongdatu, G.A.N. \& Putra, Y.H., 2018. Seasonal Time Series Forecasting using SARIMA and Holt Winter's Exponential Smoothing. In IOP Conference Series: Materials Science and Engineering (Vol. 407, No. 1, p. 012153). IOP Publishing.

Sofyan, A., 1984. Teknik dan metode peramalan, Jakarta Penerbit Fak.Ekonomi Universitas Indonesia.

Suseno, S.A., 2009. Inflasi. Jakarta: Pusat Pendidikan dan Studi Kebanksentralan (PPSK) BI.

Swandayani, D.M. \& Kusumaningtias, R., 2012. Pengaruh Inflasi, Suku Bunga, Nilai Tukar Valas dan Jumlah Uang Beredar terhadap Profitabilitas pada Perbankan Syariah di Indonesia Periode 2005-2009. AKRUAL: Jurnal Akuntansi, 3(2), 147-166.

Undang Undang Nomor 13 Tahun 2003 tentang Ketenagakerjaan.

Wei, W.W.S., 2006. Time Series Analysis Univariate and Multivariate Methods SECOND EDITION.

Wiyanti, T., Dian \& Pulungan, Reza, 2012. Peramalan Deret Waktu Menggunakan Model Fungsi Basis Radial (RBF) dan Auto Regressive Integrated Moving Average (ARIMA). 35. 175-182.

Zhang, G., 2003. Time series forecasting using a hybrid ARIMA and neural network model. J.Neurocomputing 50:159-175.

\section{Daftar Pustaka}

